\title{
Seasonal Variation of Water Quality Parameters of Zobe Reservoir Dutsinma Katsina State, Nigeria
}

\author{
Apollos TG*, Raji A and Modibbo U
}

Department of Fisheries and Aquacultural Technology, Federal University Dutsinma, Katsina State, Nigeria

\begin{abstract}
Study was conducted on the physico-chemical water properties of Zobe reservor Dutsinma, Katsina State Nigeria. Water samples were collected from four different sample stations i.e., Makera, Badole, Garhi and Bagaggadi respectively, for the period of one year (May 2015 to April 2016). Samples for Conductivity, pH, Dissolved Oxygen (DO), Temperature, Alkalinity, Turbidity, Hardness, Chloride, and Nitrate were collected during the morning hours, between 7:00 am to 9:00 am. The result showed variations in the monthly mean values of all the water quality parameters tested. The water is too turbid most especially during the beginning of raining season, despite this variation some of the values were within the tolerable range of the majority of tropical fresh water fish species. But the water cannot be used for domestic use unless it undergoes intensive treatment.
\end{abstract}

Keywords: Conductivity; pH; Dissolved oxygen (DO); Temperature; Alkalinity; Turbidity; Hardness; Chloride; Nitrate; Zobe reservoir; Dutsinma

\section{Introduction}

The most important gift for mankind is the water which plays a significant role in different vital and structural activities. Water is inevitable for all living organism as it has a great social and economic value ultimately affecting man's health. It is essentially required for industrial development, fisheries, irrigation, hydro electrical generation, human life survival and domestic animals (Keshere et al. [1]). Water covers more than $75 \%$ of the earth surface either as salt water or fresh water. It is an excellent universal solvent as well as buoyant medium. Utility of water for multiple purpose depends upon its quality. The quality of water is primarily base upon its physical, chemical, and biological characteristics. Zobe reservoir, is in the southern part of Dutsinma local government area of Katsina State, in the northern part of Nigeria. It is an earth-fill structure with a height of $19 \mathrm{~m}$ and a total length of $2,750 \mathrm{~m}$. The reservoir is located between latitude $12^{\circ} 20^{\prime}$ $34.62 \mathrm{~N}$ to $12^{\circ} 23^{\prime} 27.48 \mathrm{~N}$ and between longitude $7^{\circ} 27^{\prime} 57.12 \mathrm{E}$ to $7^{\circ} 34^{\prime} 47.68 \mathrm{E}$, in Dutsinma Local Government Area of Katsina State. The reservoir formed by the reservoir cover 4500 hectares of rocky land and during the rainy season stores 177 million cubic metres of water which is released downstream for irrigation and town water supplies. The reservoir was created for local irrigation of 8,000 hectares, power generation and water supply. Zobe reservoir has only two tributaries; these include River Karaduwa and River Gada in which River Gada drains to River Karaduwa. The Reservoir is constructed in River Karaduwa and the reservoir over Karaduwa is about 2.7 kilometres long flowing north westward to the Sokoto Basin. The sources of this reservoir bring Agricultural waste and other organic matter in the catchment area of the rivers into the reservoir especially during the raining season.

Lakes, Dams and reservoirs are invaluable ecological resources. They serve mankind in many ways providing a lot of opportunities. A large proportion of Nigerian population lives near small water bodies such as Lakes, Reservoirs, Rivers, swamp and coastal Lagoons. Many depend heavily on the resources of such water bodies as their main source of animal protein and family income. In general, however, the controlling authorities do not render sufficient assistance to develop these water resources. Nigeria is naturally endowed with large bodies of natural water (both fresh and marine) in the form of flood plains, rivers, lakes, and lagoons. Attention on water contamination and its management has become a need of the hour because of far reaching impacts on human health (Sinha et al. [2]). Continuous assessment of physical, chemical and biological parameters of water is an essential part of current water quality control programmes. Water is a vital resource for fish. It is the medium in which the fish lives; therefore, the growth of any fish is directly related to the water quality (Ajana et al. [3]). Okram et al. [4] maintained that physico-chemical features of water and sediment play important role in the structure and functioning of lake, Dams and reservoir ecosystems. The increasing emphasis on the improvement of the quality of aquatic systems and the monitoring of the surface water has highlighted the need to know what factors cause environmental deterioration (Ozean et al. [5]). Zobe reservoir serves many purposes including irrigation farming, cattle watering, and public water source and fish culture. Many supplies and miscellaneous water users also participate in this value chain. The great commercial and food value of this reservoir has brought an impact to the community. Information on water quality analysis of this reservoir particularly physical and chemical property was not documented in literature though degradation every year was noticed through inflows of water with many effluents during the rainy season. Against this background, this study was designed to investigate the physio-chemical water properties of the reservoir.

\section{Materials and Methods}

\section{Collection of samples}

Water samples were collected monthly from four different station

${ }^{*}$ Corresponding author: Apollos TG, Department of Fisheries and Aquacultural Technology, Federal University Dutsinma, Katsina State, Nigeria, Tel: 07035582187 E-mail: athandime@fudutsinma.edu.ng

Received October 06, 2016; Accepted November 02, 2016; Published November 09, 2016

Citation: Apollos TG, Raji A, Modibbo U (2016) Seasonal Variation of Water Quality Parameters of Zobe Reservoir Dutsinma Katsina State, Nigeria. Hydrol Current Res 7: 261. doi: 10.4172/2157-7587.1000261

Copyright: (c) 2016 Apollos TG, et al. This is an open-access article distributed under the terms of the Creative Commons Attribution License, which permits unrestricted use, distribution, and reproduction in any medium, provided the original author and source are credited. 


\begin{tabular}{|c|c|c|c|c|c|c|c|c|c|}
\hline \multirow[b]{2}{*}{ Months } & \multicolumn{9}{|c|}{ Parameters } \\
\hline & $\begin{array}{c}\text { Temperature } \\
\left({ }^{\circ} \mathrm{C}\right)\end{array}$ & $\begin{array}{l}\text { Conductivity } \\
(\mathrm{u} \Omega / \mathrm{cm})\end{array}$ & $\mathrm{pH}$ & $\begin{array}{c}\text { Dissolved } \\
\text { oxygen (mg/l) }\end{array}$ & $\begin{array}{l}\text { Alkalinity } \\
\text { (mg/l) }\end{array}$ & $\begin{array}{l}\text { Turbidity } \\
\text { (cm) }\end{array}$ & $\begin{array}{l}\text { Hardness } \\
(\mathrm{mg} / \mathrm{l})\end{array}$ & Chloride (mg/l) & Nitrate (mg/l) \\
\hline May & $32.40 \pm 2.73^{b}$ & $84.32 \pm 7.17^{a}$ & $6.53 \pm 7.17^{a}$ & $6.80 \pm 7.19^{a}$ & $38.03 \pm 2.13^{a}$ & $0.34 \pm 0.01^{a}$ & $64.40 \pm 1.60^{b}$ & $10.78 \pm 3.23^{b}$ & $2.76 \pm 0.21$ \\
\hline June & $30.80 \pm 0.19^{b}$ & $92.00 \pm 2.17^{b}$ & $6.56 \pm 4.18^{a}$ & $7.30 \pm 2.34^{a}$ & $32.02 \pm 3.12^{\mathrm{b}}$ & $1.01 \pm 0.02^{\mathrm{b}}$ & $65.20 \pm 2.40^{\mathrm{b}}$ & $12.24 \pm 1.03^{b}$ & $0.60 \pm 0.83^{a}$ \\
\hline July & $29.40 \pm 0.58^{b}$ & $0.60 \pm 0.15^{a}$ & $7.01 \pm 2.12^{\mathrm{a}}$ & $8.23 \pm 3.21^{c}$ & $22.09 \pm 0.13^{a}$ & $1.11 \pm 0.02^{b}$ & $59.60 \pm 1.33^{b}$ & $9.20 \pm 2.13^{\mathrm{a}}$ & $0.34 \pm 0.43^{a}$ \\
\hline August & $26.60 \pm 0.68^{a}$ & $175.80 \pm 5.77^{c}$ & $7.32 \pm 0.23^{b}$ & $8.90 \pm 1.43^{c}$ & $23.03 \pm 1.42$ & $1.06 \pm 0.02^{b}$ & $51.60 \pm 4.17^{b}$ & $13.92 \pm 2.15^{b}$ & $0.58 \pm 0.78^{a}$ \\
\hline September & $26.30 \pm 0.37^{a}$ & $160.60 \pm 5.11^{c}$ & $7.12 \pm 7.34^{b}$ & $8.10 \pm 2.13^{c}$ & $21.12 \pm 0.21^{a}$ & $1.16 \pm 0.01^{b}$ & $52.40 \pm 4.31^{b}$ & $14.52 \pm 0.23^{b}$ & $0.26 \pm 0.46^{a}$ \\
\hline October & $26.00 \pm 0.32^{\mathrm{a}}$ & $162.60 \pm 2.33^{c}$ & $6.73 \pm 4.67^{a}$ & $7.23 \pm 6.52^{\mathrm{b}}$ & $38.01 \pm 2.63^{b}$ & $0.98 \pm 0.03^{a}$ & $47.70 \pm 1.04^{a}$ & $7.68 \pm 3.47^{a}$ & $0.24 \pm 0.63^{a}$ \\
\hline November & $27.32 \pm 0.42^{\mathrm{a}}$ & $80.00 \pm 2.76^{a}$ & $7.23 \pm 2.27^{b}$ & $7.10 \pm 8.23^{b}$ & $25.89 \pm 0.90^{\mathrm{a}}$ & $0.87 \pm 0.01^{\mathrm{a}}$ & $42.30 \pm 0.80^{a}$ & $6.24 \pm 0.48^{a}$ & $2.06 \pm 0.94^{b}$ \\
\hline December & $26.80 \pm 0.47^{a}$ & $149.00 \pm 3.45^{c}$ & $7.00 \pm 3.19^{b}$ & $6.64 \pm 5.21^{a}$ & $20.93 \pm 6.21^{a}$ & $0.86 \pm 0.03^{a}$ & $48.20 \pm 3.02^{a}$ & $5.98 \pm 1.93^{a}$ & $1.42 \pm 0.83^{b}$ \\
\hline January & $26.45 \pm 0.32^{\mathrm{a}}$ & $142.02 \pm 2.12^{\mathrm{c}}$ & $6.92 \pm 1.43^{a}$ & $7.30 \pm 9.12^{\mathrm{b}}$ & $31.02 \pm 1.62^{b}$ & $0.87 \pm 0.02^{\mathrm{a}}$ & $33.60 \pm 0.68^{a}$ & $8.64 \pm 2.07^{a}$ & $1.42 \pm 0.83^{b}$ \\
\hline February & $26.89 \pm 0.67^{a}$ & $153.41 \pm 6.74^{c}$ & $6.48 \pm 7.12^{\mathrm{a}}$ & $7.34 \pm 6.52^{b}$ & $37.14 \pm 0.46^{b}$ & $0.79 \pm 0.03^{a}$ & $41.70 \pm 1.56^{a}$ & $11.16 \pm 0.01^{\mathrm{b}}$ & $2.21 \pm 0.34^{b}$ \\
\hline March & $27.97 \pm 0.74^{a}$ & $84.87 \pm 0.34^{a}$ & $7.12 \pm 5.23^{b}$ & $6.98 \pm 7.31^{\mathrm{a}}$ & $23.17 \pm 2.20^{\mathrm{a}}$ & $0.74 \pm 0.02^{\mathrm{a}}$ & $47.60 \pm 2.44^{a}$ & $8.86 \pm 1.87^{a}$ & $2.05 \pm 0.75^{b}$ \\
\hline April & $30.56 \pm 0.68^{b}$ & $94.23 \pm 3.41^{b}$ & $6.41 \pm 3.41^{\mathrm{a}}$ & $6.90 \pm 3.28^{a}$ & $28.26 \pm 0.56^{a}$ & $0.74 \pm 0.01^{a}$ & $54.32 \pm 0.52^{b}$ & $8.44 \pm 1.41^{\mathrm{a}}$ & $2.23 \pm 0.01^{b}$ \\
\hline $\begin{array}{l}\text { Annual } \\
\text { Mean }(X)\end{array}$ & $28.12 \pm 0.53$ & $121.59 \pm 4.36$ & $6.87 \pm 4.6$ & $7.39 \pm 6.23$ & $28.39 \pm 3.12$ & $0.88 \pm 0.02$ & $50.71 \pm 1.32$ & $9.81 \pm 2.32$ & $1.38 \pm 0.43$ \\
\hline
\end{tabular}

Table 1: Monthly mean value of Annual variation of water quality parameters of four sampling station of Zobe Reservoir.

Makera, Badole, Garhi and Bagaggadi respectively, from east to the west of the reservoir. The samples were collected for the period of one year May 2015 to April 2016. All the samples were collected during the morning hours, between 7:00 am to 9:00 am.

\section{Analysis of samples}

All the water quality parameters collected i.e., Conductivity, $\mathrm{pH}$, Dissolved oxygen (DO), Temperature, Alkalinity, Turbidity, Hardness, Chloride and Nitrate, were analysed using Hatch Kits immediately after collection at the reservoir. Calcium, Magnesium and Total Hardness were analysed at fisheries and Aquaculture Laboratory Federal University Dutsinma Katsina State in line with the standard methods described by Trivedia et al. [6-8].

\section{Data analysis}

All data collected on Conductivities, $\mathrm{pH}$, Dissolved oxygen (DO), Temperature, Alkalinity, Turbidity, Hardness, Chloride and Nitrate, were subjected to one way analysis of variance (ANOVA) while mean were separated using Duncan multiple range test (Duncan [9]).

\section{Results and Discussion}

The Table 1 shows the results of all the physio-chemical water quality parameters of the reservoir. Temperature of the surface waters of Zobe reservoir generally followed a similar pattern throughout the monitoring period. Temperatures increased throughout the period with average of $28.12^{\circ} \mathrm{C}$ and peaked in May and April at about $32.40^{\circ} \mathrm{C}$ and $30.80^{\circ} \mathrm{C}$ (Table 1). Temperatures throughout the stations in all months were somewhat uniform. In October, the temperature of the water was observed to be low with monthly mean of $26^{\circ} \mathrm{C}$.

Conductivity among the stations and months fluctuate. Conductivity at most months averaged about $121.59 \mathrm{u} \Omega / \mathrm{cm}$, throughout the monitoring period and ranged from 175.80 to $80.60 \mathrm{u} \Omega / \mathrm{cm}$ (Table 1). Conductivity was typically higher in August. At this month, conductivity averaged $175.80 \mathrm{u} \Omega / \mathrm{cm}$. In most months, measures were generally almost uniform throughout, but followed a slight increasing trend as the season progressed. This is in corroboration with the report of other workers (Obhahie et al. [10]). Dissolved oxygen (DO) in the reservoir fluctuate during the study period. Concentrations among all stations generally averaged $7.39 \mathrm{mg} / \mathrm{L}$ over the monitoring period and ranged from 6.34 to $8.90 \mathrm{mg} / \mathrm{L}$ (Table 1). The dissolved oxygen content of the reservoir is within the range recommended for fish production according to Viveen et al. [11]. Alkalinity of Zobe reservoir was high during the period of the research. Concentrations measured at all stations and months averaged $28.39 \mathrm{mg} / \mathrm{L}$ and ranged from 20.93 to $38.03 \mathrm{mg} / \mathrm{L}$ throughout the monitoring period (Table 1). The PADEP standard is a minimum concentration of $20 \mathrm{mg} / \mathrm{L}$.

Measures of $\mathrm{pH}$ generally followed a similar pattern during period of study. Among all stations, $\mathrm{pH}$ generally averaged about 6.87 throughout the monitoring period and monthly ranged from 6.41 to 7.32 (Table 1). On most monitoring dates, measures of $\mathrm{pH}$ were relatively uniform throughout the stations. In August, $\mathrm{pH}$ was highest and averaged about 7.32. In April, $\mathrm{pH}$ was lowest averaging 6.41. The water quality standard for $\mathrm{pH}$ is a range of acceptable measures between 6 and 9. Throughout the monitoring period, measures of $\mathrm{pH}$ at all stations were within the limits of the water quality standard. This is in agreement with the report of Ugwu et al. [12].

The turbidity of the Dam was noticed to be high especially during the peak of the raining season around July and August while the lowest value of $0.34 \mathrm{~cm}$ was recorded in May (Table 1). In a previous study by Ajayi [13], he observed that the favorable range of Sechi-disc reading for aquaculture in the tropics is within the range of 0.30 to $0.60 \mathrm{~cm}$. The turbidity of the water in the reservoir is above the normal standard. The natural turbidity of the water is largely dependent on the underlying geology and soils within the surrounding watershed (Boyd [14]).

The mean total hardness of the reservoir water was found to be $50.71 \mathrm{mg} / \mathrm{l}$ with the highest value recorded 65.20 in June. Hardness of water should not exceed the standard value set up by WHO (1984). The average chloride value of the reservoir water was measured to be $9.81 \pm 2.32$ throughout the period of the study and the values do not exceed the standard values for Aquaculture. The average value for mean monthly Nitrate was $1.38 \pm 0.43$ this value is within the range for fish farming.

\section{Conclusion}

It is therefore concluded that despite the contamination of the Zobe reservoir with many effluents, its water is still amenable for aquaculture activities. Some aquatic and terrestrial fungi might be introduced into the reservoir to make it more productive and reduce the turbidity of the water. Hence, the Dam could be used for fishing, irrigation, hydroelectric power generation, domestic water supply and other related water usage. 
Citation: Apollos TG, Raji A, Modibbo U (2016) Seasonal Variation of Water Quality Parameters of Zobe Reservoir Dutsinma Katsina State, Nigeria. Hydrol Current Res 7: 261. doi: 10.4172/2157-7587.1000261

Page 3 of 3

\section{References}

1. Keshere OJ, Mustpha IM, Sani MU, Goni IS (2007) Water an important gift for mankind's. Alhassan Publisher, Yola, Nigeria.

2. Singha DK, Srivastava AK (1995) Physico-chemical characteristics of river Sai at Rae Barch, India. J Environ Health 37: 205-210.

3. Ajana AM, Adekoye BB, Olunuga OA, Ayankanuwo JO (2006) Practical fish farming. Alliance for Community Information, Nigeria.

4. Okram ID, Sharma BM, Singh EJ (2003) Study of some physicochemical Properties of Wathou Lake, Manipur. Environ Biol Conserv 8: 13-17.

5. Ozmen MA, Güngördü A, Kucukbay FZ, Gülar RE (2006) Monitoring the Effect of water pollution on cyprinus carpio in Karakaya Dam Lake. Turkey Ecotoxicol 15: 157-169.

6. Trivedi RK, Goel PK (1986) Chemical and biological methods for water pollution studies. Environmental Publications, Karad.

7. Saxena D (1990) Environmental analysis of water, soil and air. Agrobotanical Publishers, India, p: 184

8. American Public Health Association (APHA) (1992) Standard Methods for the
Examination of Water and Wastewater. 18th edn. Prepared by the American Public Health Association, the American Water Works Association and the Water Pollution Control Federation. Washington DC, USA.

9. Duncan D (2006) Multiple Range Test and multiple F-test. Biometrics 11: 1-42.

10. Obhahie Al, Ugwaka KA, Ugwu LL, Adesiyan FA (2007) Effect of industrial effluent and municipal waste on water conductivity and dissolved solids, Sulphate and phosphate ions concentration of Ogba River Benin City. Niger J Fish Int 2: 277-283.

11. Viveen WJAR, Richer CJJ, Von PGWJ, Jansean JAL, Huisman EA (1986) Practical Manual of culture of African Cat fish Clarias gariepinus Netherlands. Department of Fish Culture and Fisheries of the Agricultural University of Wageningen, The Netherlands.

12. Ugwu LC, Mgbenka BO (2006) Fisheries and Wild Life Management. Jones Communication, Nigeria.

13. Ajayi O (2006) A guide to primary productivity in fish pond management Innovation Technology Nigeria.

14. Boyd CE (1981) Water quality in warm water fish pond agricultural experimenta Station. 2nd edn. Aubum University Craft Master Publication Co., Alabama, USA. 